Ali Akbar

\title{
Pengaruh Variabel Internal Perbankan Terhadap Kinerja Bank Konvensional di Indonesia
}

\author{
Ali Akbar \\ Fakultas Ekonomi, Universitas Batanghari Jambi, Indonesia \\ Correspondence email: aliakbar060873@gmail.com
}

\begin{abstract}
This research is to know the influence of internal variables of banking (amount of credit and operational expense than operating income (BOPO)) on the performance of conventional banks. The population in this research is the whole of conventional commercial banks in Indonesia year of 2010-2017. The sampel is the conventional commercial banks by as much as 14 banks, with time series data. The method used is the analysis of partial least square (PLS). The results showed that internal variables of banking (amount of credit, BOPO) negative and no significant effect on performance of conventional banks (CAR, NPL, ROA, LDR) and amount of credit credit is an indicator of a dominant influence variation/change from a conventional banks performance factors (CAR, NPL, ROA and $L D R$ ).
\end{abstract}

Keywords: Amount of Credit, BOPO, CAR, NPL, ROA, LDR.

\section{PENDAHULUAN}

Peran pemerintah dalam perekonomian modern dapat diklasifikasikan dalam tiga kelompok besar : peran alokasi, peran distribusi dan peran stabilisasi (Mangkoesoebroto, 1993). World Bank (1997) menyebutkan lima tugas pokok sebagai inti misi pemerintah, yaitu : membangun landasan hukum, memelihara lingkungan, kebijakan yang bersifat tidak mendistorsi, termasuk di dalamnya stabilitas perekonomian secara makro, melakukan investasi dalam layanan-layanan dan infrastruktur sosial, melindungi kelompok lemah dan melindungi lingkungan. Dalam literatur ekonomi makro, secara lebih spesifik disebutkan bahwa peran pemerintah dalam perekonomian dijalankan melalui dua bentuk kebijakan, yaitu kebijakan moneter dan kebijakan fiskal. Menurut Agenor dan Montiel (2008), dalam perekonomian media transmisi pengaruh kebijakan moneter pada dasarnya adalah sektor keuangan, khususnya sektor perbankan, melalui proses penciptaan uang giral, uang kuasi dan kredit. Efektivitas variabel moneter (suku bunga, nilai tukar, jumlah uang beredar) dalam mempengaruhi pendapatan nasional sangat dipengaruhi oleh kinerja sektor perbankan, begitu pula sebaliknya, efektivitas variabel moneter dapat pula menjadi indikator dari kinerja sektor perbankan, disamping efektivitas variabel internal perbankan seperti antara lain kebijakan pemberian kredit dan kebijakan operasional (efisiensi). (Adisetiawan \& Yunan, 2016)

Keberhasilan suatu sistem perbankan dapat dilihat dari kinerjanya dalam mengalokasikan sumber dana yang dihimpun untuk mengalirkannya kepada pihak-pihak yang membutuhkan dana tersebut (fungsi bank sebagai intermediary). Nantinya keberhasilan itu diharapkan dapat meningkatkan pertumbuhan ekonomi suatu negara. Hal ini jelas sesuai dengan sasaran yang ingin dicapai dari suatu lembaga keuangan yang didasarkan pada UU No. 10 Tahun 1998 yaitu menciptakan struktur perbankan domestik yang sehat yang mampu memenuhi kebutuhan masyarakat dan mendorong pembangunan ekonomi nasional yang berkesinambungan (Iskandar, 2008). Sektor perbankan Indonesia, di dalam perkembangannya selalu mengesankan, namun ketika pertengahan tahun 1997, sektor perbankan di Indonesia mengalami krisis skala nasional yang sangat parah. Triyono dan Utomo (2004), selama periode prakrisis, menemukan elastisitas jangka pendek dan jangka panjang instrumen kebijakan moneter (jumlah uang beredar) masing-masing adalah sebesar $-0,4012$ dan -1,2938. Tidak stabilnya sistem konvensional yang ada menyebabkan terjadinya krisis di berbagai belahan dunia secara berulang dari masa ke masa yang membuat masyarakat mengalami kesulitan ekonomi. Peristiwa ini dapat dilihat dari penelitian yang dilakukan Laeven dan Valencia (2008), hasil penelitiannya menemukan bahwa sepanjang tahun 1970-2007 terdapat 447 krisis yang terbagi menjadi 395 krisis keuangan (krisis perbankan, krisis mata uang dan krisis pembayaran hutang pemerintah), 42 twin crisis dan 10 triple crisis. Selain itu, krisis juga pernah melanda Indonesia dan berdampak signifikan terhadap pertumbuhan ekonomi negara ini yaitu seperti yang terjadi pada krisis multidimensi tahun 19971998 dan krisis keuangan global tahun 2007-2008. 
Krisis berikutnya adalah krisis yang terjadi pada tahun 2007-2008 yang dikenal dengan subprime mortgage crisis. Berawal dari krisis kredit macet perumahan di Amerika semester akhir 2007, dalam hitungan bulan krisis tersebut menyebar kepada sektor keuangan dan juga sektor riil di berbagai negara kawasan Eropa dan Amerika. Akibat lebih lanjut dari krisis finansial global ini adalah ekonomi dunia yang mengalami perlambatan sangat tajam pada triwulan terakhir 2008. AS, Inggris, Jepang serta negara maju lainnya mengalami fase resesi yang cukup serius pada tahun 2009. Krisis keuangan yang dialami Indonesia pada tahun 2008 berdampak langsung terhadap IHSG yang terus menurun akibat terjadinya capital outflow besar-besaran di pasar saham dan melemahnya nilai tukar mata uang rupiah terhadap dollar AS. Sementara itu, gejolak instabilitas luar negeri pun terlihat dengan anjloknya nilai tukar rupiah terhadap dollar AS (kurs tengah) yang mencapai angka Rp10.950 per dollar AS pada tahun 2008. Begitupun pada tahun 2013 - 2016 dimana nilai tukar rupiah terhadap dollar AS (kurs tengah) juga anjlok pada angka Rp12.189 - Rp13.795 per dollar AS. Tahun 2013 nilai tukar rupiah terhadap dollar AS yaitu Rp12.189, tahun 2014 nilai tukar rupiah terhadap dollar AS mengalami depresiasi yaitu Rp12.440 dan tahun 2015 nilai tukar rupiah terhadap dollar AS mengalami depresiasi yang cukup tinggi yaitu menjadi Rp13.795, sedangkan pada tahun 2016 nilai tukar rupiah terhadap dollar AS sedikit mengalami penguatan dibandingkan tahun 2015 yaitu Rp13.436 (menguat sebesar Rp.359). Hal ini tidak jauh berbeda dengan dampak yang ditimbulkan oleh krisis multidimensi 1998 di Indonesia yang menyebabkan terjadinya krisis mata uang domestik.

Selama krisis maupun pascakrisis, sektor perbankan mengalami rangkaian deregulasi berkelanjutan (baik dari sisi eksternal maupun internal bank) untuk memperbaiki kinerja perbankan dan mengembalikan kepercayaan masyarakat serta untuk mencegah terulangnya kembali krisis nasional sektor perbankan. Kondisi perbankan saat ini mendorong pihak- pihak yang terlibat di dalamnya untuk melakukan penilaian atas kesehatan bank. Salah satu pihak yang perlu mengetahui kinerja dari sebuah bank adalah investor sebab semakin baik kinerja bank tersebut maka jaminan keamanan atas dana yang diinvestasikan juga semakin besar. Investor dapat mengetahui kinerja suatu bank, dengan menggunakan rasio keuangan. Hal ini sesuai dengan pernyataan Muljono (1999) bahwa perbandingan dalam bentuk rasio menghasilkan angka yang lebih obyektif, karena pengukuran kinerja tersebut lebih dapat dibandingkan dengan bank-bank yang lain ataupun dengan periode sebelumnya. (Adisetiawan, 2011)

Rasio keuangan perbankan (bank umum konvensional), antara lain terdiri dari :

1. Rasio permodalan (solvabilitas), diantaranya adalah : Capital Adequacy Ratio (CAR).

Rasio Capital Adequacy Ratio (CAR) menunjukkan kemampuan bank bank dalam mempertahankan modal yang mencukupi dan kemampuan manajemen bank dalam mengidentifikasi, mengawasi dan mengontrol risiko-risiko yang timbul yang dapat berpengaruh terhadap besarnya modal bank.

2. Rasio kualitas aktiva produktif (earnings asset quality), diantaranya adalah : Non Performing Loan (NPL).

Rasio Non Perfoming Loan (NPL) menunjukkan kemampuan manajemen bank untuk mengelola kredit/ pembiayaan bermasalah dari total kredit/pembiayaan yang diberikan oleh bank.

3. Rasio rentabilitas (earning), diantaranya adalah : Return On Assets (ROA).

Rasio Return On Asset (ROA) menunjukkan berapa persen diperoleh laba sebelum pajak bila diukur dari rata-rata total aset.

4. Rasio likuiditas (liquidity), diantaranya adalah : Loan to Deposit Ratio (LDR.

Rasio Loan to Deposit Ratio (LDR) ini menggambarkan seberapa jauh kemampuan bank dalam membayar kembali penarikan dana yang dilakukan deposan dengan mengandalkan kredit yang diberikan sebagai sumber likuiditasnya. Almilia dan Herdiningtyas (2005) rasio Loan to Deposit Ratio (LDR)/Financing to Deposit Ratio (FDR) menunjukkan kemampuan suatu bank dalam menyediakan dana kepada debiturnya dengan modal yang dimiliki oleh bank maupun dana yang dapat dikumpulkan dari masyarakat (Almilia dan Herdiningtyas, 2005).

\section{Kerangka Pemikiran}

Salah satu kerangka pemikiran yang dapat digunakan untuk menilai kinerja Bank adalah melalui informasi keuangan yang dikeluarkan oleh Bank, yaitu informasi mengenai kondisi keuangan dan perkembangan hasil usaha suatu Bank. Laporan keuangan merupakan alat utama untuk memberikan informasi kepada para pemakai ekstenal. Menurut Financial Accounting Standards Board (FASB) tahun 
1978 (konsep No.1 : par 34) yang berbunyi sebagai berikut : Financial Reporting should provide information that is useful to present and potential investors and creditors and other users in making rational investment, credit, and similar decicions. That information should be comprehensible to those who have a reasonable understanding of business and economic activities and are willing to study the information".

Konsep tersebut maka laporan keuangan harus dapat membantu investor dan kreditor untuk menginterprestasikan keadaan suatu Bank. Weston dan Copeland (1997) mendefinisikan laporan keuangan sebagai laporan yang berisi informasi tentang peristiwa perusahaan di masa lampau dan dapat dipakai sebagai dasar untuk penetapan kebijakan perusahaan di masa yang akan datang. Dari laporan keuangan dapat diinformasikan gambaran berbagai aktivitas akuntansi bank secara periodik dan dari laporan keuangan itu pula dapat diadakan penilaian terhadap kinerja keuangan Bank yang bersangkutan. Dalam menilai kinerja keuangan suatu perusahaan, investor dapat menganalisa informasi yang terkandung pada laporan keuangan Bank. Sektor perbankan sangat penting untuk menunjang dan menggerakkan perekonomian suatu negara dengan memberikan pinjaman (kredit) kepada masyarakat yang membutuhkan untuk mengembangkan usahanya. Oleh karena itu sektor perbankan haruslah sehat dan kuat, sehingga dapat bertahan apabila terjadi krisis ekonomi/keuangan. Bank yang sehat dan kuat dapat dilihat dari performance (kinerja) dari Bank tersebut. Bank yang tidak sehat dan kuat akan mengalami kegagalan dalam menjalankan operasionalnya sehingga hal tersebut dapat berdampak kepada perekonomian suatu negara. Karena pentingnya performance (kinerja) suatu Bank, maka timbul pemikiran bahwa ada pengaruh kebijakan internal perbankan (kebijakan pemberian kredit/total kredit, kebijakan operasional (efisiensi)/BOPO) terhadap kinerja bank konvensional (CAR, NPL, ROA, LDR) di Indonesia.

\begin{tabular}{|l|l|}
\hline \multicolumn{1}{|c|}{ Variabel Internal Bank Konvensional } & \multicolumn{1}{|l|}{ Kinerja Bank Konvensional } \\
\hline $\begin{array}{l}\text { - Kebijakan Pemberian Kredit/Total Kredit (X1) } \\
\text { - Kebijakan Operasional (Efisiensi)/BOPO (X2) }\end{array}$
\end{tabular}$\longrightarrow$\begin{tabular}{l}
- CAR (Y1) \\
- NPL (Y2) \\
- ROA (Y3) \\
- LDR (Y4) \\
\hline
\end{tabular}

\section{Gambar 1 \\ Kerangka Konseptual Pemikiran}

\section{METODE PENELITIAN}

Populasi yang digunakan dalam penelitian ini adalah bank umum konvensional yang ada (terdaftar) di Bank Indonesia periode 2010 - 2017. Berdasarkan Stastistik Perbankan Indonesia (SPI) bulan Juni 2017 yang diterbitkan oleh Otoritas Jasa Keuangan dan dapat diakses melalui website www.ojk.go.id pada menu Data dan Statistik-Perbankan, dimana jumlah bank umum konvensional sebanyak 102 (seratus dua) bank. Sedangkan sampel adalah sebagian dari objek yang diteliti. 102 (seratus dua) bank umum konvensional, sampel yang digunakan/diambil sebanyak 14 (empat belas) bank umum konvensional. Adapun kriteria pemilihan sampel adalah sebagai berikut :

- Bank umum konvensional yang tercatat di Bank Indonesia dan masih beroperasi selama kurun waktu penelitian (tahun 2010 - 2017).

- Laporan keuangan Bank yang diteliti (perode tahun 2010 - 2017) tersedia secara lengkap baik di Bank Indonesia (BI), Otoritas Jasa Keuangan (OJK) dan website resmi masing-masing Bank. Dalam penelitian ini jenis data yang dipergunakan adalah data sekunder yaitu : laporan keuangan triwulanan bank umum konvensional di Indonesia periode 2010 - 2017 serta data lainnya yang tersedia di Bank Indonesia (BI) dan Otoritas Jasa Keuangan (OJK) dan sumber-sumber resmi lainnya yang mendukung penelitian ini.

Metode observasi yaitu dengan pengamatan langsung terhadap Laporan Keuangan Tahunan pada 14 (empat belas) bank umum konvensional, Metode pengumpulan data di dalam penelitian ini adalah :

1. Periode 2010 - 2017. 
2. Metode penelitian kepustakaan (library research) yaitu dengan cara mempelajari dan menelaah berbagai literatur-literatur yang berhubungan dengan masalah yang akan diteliti.

Dalam penelitian ini, peneliti menggunakan metode analisis Deskriptif Inferensial dan Deskriptif Kuantitatif, yaitu :

1. Deskriftif Inferensial yaitu : suatu metode untuk menganalisis data keuangan dengan cara analisis statistik induktif.

2. Deskriftif Kuatitatif yaitu : suatu metode yang digunakan untuk menganalisis terhadap data keuangan yang ada dengan cara mengaplikasikan teori atau konsep dengan fakta.

Penelitian yang dilakukan data yang diperoleh dan hipotesis yang diajukan akan dianalisis dan diuji dengan alat analisis/uji statistik persamaan struktural berbasis variance atau Structural Equation Modeling (SEM) - Partial Least Square (PLS) dengan menggunakan program/sofware SmartPLS. Adapun pertimbangan menggunakan model SEM-PLS, karena kemampuannya untuk mengukur konstruk melalui indikator-indikatornya, menganalisis variabel indikator, variabel laten, dan kekeliruan pengukurannya serta dapat melakukan analisis secara langsung (tidak satu persatu diregresi) hubungan antara variabel bebas (independen variabel/eksogen) dengan variabel terikat (dependen variabel/endogen). Menurut Imam Ghozali (2006), Partial Least Square (PLS) merupakan metode analisis yang powerful oleh karena tidak mengasumsikan data harus dengan pengukuran skala tertentu, jumlah sampel kecil. Tujuan Partial Least Square (PLS) adalah membantu peneliti untuk mendapatkan nilai variabel laten untuk tujuan prediksi.

\section{HASIL DAN PEMBAHASAN}

Pengaruh Variabel Internal Perbankan Terhadap Kinerja Bank Konvensional

Tabel 1

Nilai Koefisien dan t-Statistik Analisa Jalur

\begin{tabular}{lcccrr}
\hline Variabel Laten & $\begin{array}{c}\text { Original } \\
\text { Sample (O) }\end{array}$ & $\begin{array}{c}\text { Sample Mean } \\
(\mathrm{M})\end{array}$ & $\begin{array}{c}\text { Standard } \\
\text { Deviation } \\
\text { (STDEV) }\end{array}$ & $\begin{array}{c}\text { Standard Error } \\
\text { (STERR) }\end{array}$ & $\begin{array}{c}\text { t-Statistics } \\
(|\mathrm{O} / \mathrm{STDEV}|)\end{array}$ \\
\hline VIK -> KBK & $-0,358$ & $-0,078$ & 0,397 & 0,397 & 0,903 \\
\hline
\end{tabular}

Sumber : Hasil olahan

Keterangan : VIK = Variabel Internal Bank Konvensional; KBK = Kinerja Bank Konvensional

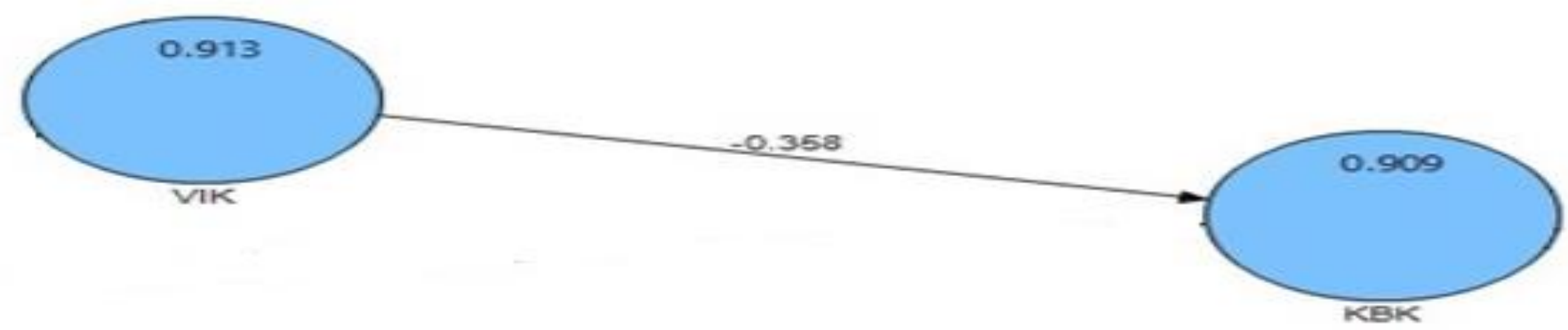

Gambar 2

Pengaruh Variabel Internal Perbankan Terhadap Kinerja Bank Konvensional

Kinerja keuangan bank adalah gambaran kondisi keuangan bank sebagai penghimpun dan penyalur dana pada periode tertentu. Hasil kinerja dapat menampilkan kelebihan maupun kekurangan suatu bank pada setiap periodenya. Faktor internal bank merupakan faktor yang terjadi didalam bank serta dapat mempengaruhi keputusan manajemen bank kaitannya dalam pengambilan kebijakan dan strategi operasional bank, faktor dari dalam tersebut meliputi kegiatan operasional bank. Kegiatan operasional bank ini menghimpun dana dan menyalurkan kredit yang nantinya dapat menciptakan asset perusahaan dan berpengaruh terhadap besarnya BOPO. Hasil penelitian menunjukkan bahwa besarnya pengaruh variabel internal Bank Konvensional (VIK) terhadap kinerja Bank Konvensional (KBK) dapat dilihat dari besarnya original sample. Dalam hal ini besarnya pengaruh variabel internal Bank Konvensional terhadap kinerja 
Bank Konvensional adalah sebesar -0,358. Besaran ini mengindikasikan bahwa apabila terjadi perubahan kenaikan dalam variabel internal Bank Konvensional sebesar 10\% maka akan mengakibatkan terjadinya penurunan dalam kinerja Bank Konvensional sebesar 3,58\%. Hasil pengujian menunjukkan bahwa t.statistik $0,90<1,96$, berarti terima H0. Dengan kata lain tidak terdapat pengaruh yang signifikan variabel internal Bank Konvensional terhadap kinerja Bank Konvensional. Hasil penelitian ini tidak sejalan dengan Kesumayuda (2016) yang menunjukkan bahwa faktor internal Bank Konvensional berpengaruh signifikan dengan arah hubungan yang positif terhadap kinerja keuangan. Berarti bahwa semakin tinggi faktor internal : penyaluran kredit dan BOPO akan menghasilkan kinerja Bank Konvensional yang semakin baik terutama terhadap Capital Adequacy Ratio (CAR) dan Loan to Deposit Ratio (LDR). Selanjutnya Kamalia, Sunu dan Rahmawati (2013) bahwa faktor internal Bank Konvensional berpengaruh signifikan terhadap kinerja Bank yang dibuktikan dengan nilai $p$-value sebesar 0,022 yang lebih kecil dari 0,05 dan nilai koefisien jalur sebesar 0,077 artinya bahwa variabel faktor internal yang terdiri dari indikator Debt To Total Asset (DTA) dan Capital Adequacy Ratio (CAR) berpengaruh signifikan terhadap kinerja bank yang diukur menggunakan indikator Return On Asset (ROA) dan Return On Equity (ROE). Kesumayuda (2016) yang menunjukkan bahwa faktor internal Bank Konvensional berpengaruh signifikan dengan arah hubungan yang positif terhadap kinerja keuangan. Berarti bahwa semakin tinggi faktor internal ; penyaluran kredit dan BOPO akan menghasilkan kinerja Bank Konvensional yang semakin baik terutama terhadap Capital Adequacy Ratio (CAR) dan Loan to Deposit Ratio (LDR). Selanjutnya Kamalia, Sunu dan Rahmawati (2013) bahwa faktor internal Bank Konvensional berpengaruh signifikan terhadap kinerja Bank yang dibuktikan dengan nilai $p$ value sebesar 0,022 yang lebih kecil dari 0,05 dan nilai koefisien jalur sebesar 0,077 artinya bahwa variabel faktor internal yang terdiri dari indikator Debt To Total Asset (DTA) dan Capital Adequacy Ratio (CAR) berpengaruh signifikan terhadap kinerja bank yang diukur menggunakan indikator Return On Asset (ROA) dan Return On Equity (ROE). Penelitian yang sejalan dengan hasil analisis penelitian ini Ponco (2008) bahwa semakin besar kebijakan penyaluran kredit dan BOPO maka akan berpengaruh negatif terhadap bank yang dapat dikategorikan tidak efisien dalam menjalankan operasinya dan penyaluran kredit. Hal ini berarti variabel internal Bank Konvensional dari aspek penyaluran kredit dan BOPO hanya akan berpengaruh positif terhadap kinerja bank apabila bank mampu meningkatkan efisiensi dalam melakukan kegiatan operasinya dan penyaluran kredit.

\section{SIMPULAN}

Variabel internal perbankan (total kredit, BOPO) berpengaruh negatif dan tidak signifikan terhadap kinerja Bank Konvensional (CAR, NPL, ROA, LDR). Total kredit merupakan indikator dominan yang mempengaruhi variasi/perubahan dari faktor kinerja Bank Konvensional (CAR, NPL, ROA dan LDR).

\section{DAFTAR PUSTAKA}

Adisetiawan, R., and Yunan Surono, 2016, Earning Management and Accounting Information Value: Impact and Relevance, Business, Management and Economics Research, 2(10), 170-179

Adisetiawan, R., 2011, Relevansi Nilai Informasi Akuntansi pada Indeks LQ45, Jurnal Akuntabilitas, 1(1), 119-126

Agenor, Pierre-Richard and Montiel, Peter J. 2008. Development Macroeconomics. 3rd Edition. Princeton University Press. New Jersey.

Almilia, Luciana Spica, dan Winny Herdiningtyas. 2005. Analisis Rasio Camel Terhadap Prediksi Kondisi Bermasalah Pada Lembaga Perbankan Periode 2000 - 2002. Jurnal Akuntansi dan Keuangan Volume 7 Nomor 2, STIE Perbanas, Surabaya.

Financial Accounting Standards Board (FASB) tahun 1978 (konsep No.1 : par 34).

Ghozali, Imam. 2006. Structural Equation Modeling: Metode Alternatif dengan Partial Least Square. Universitas Diponegoro. Semarang.

Iskandar, Syamsu. 2008. Bank dan Lembaga Keuangan Lain. PT.Semesta Asa Bersama. Jakarta.

Kesumayuda, I B Nyoman, Made Suyana Utama, dan I B P Purbadharmaja. 2016. Analisis Faktor Internal dan Eksternal Yang Mempengaruhi Kinerja Keuangan Bank Pembangunan Daerah di Indonesia Periode 2010 - 2013. Jurnal Buletin Studi Ekonomi. Vo.21. No.1. Universitas Udayana.

Laeven, Luc and Valencia, Fabian. 2008. Sistemic Banking Crises : A New Database. IMF Working Paper. 
Mangkoesoebroto, Guritno. 1993. Ekonomi Publik. Edisi 3. BPFE. Yogyakarta.

Muljono, Teguh Pudjo. 1999. Analisa Laporan Keuangan Untuk Perbankan. Edisi Revisi 1999. Cetakan 6. Djambatan. Jakarta.

Octaviyanty, Kamalia, Sunu Priyawan, dan Tri Ratnawati. 2013. Analisis Faktor Internal dan Eksternal Yang Mempengaruhi Kinerja Bank Umum di Indonesia Periode 2008-2011. DIE. Jurnal Ilmu Ekonomi \& Manajemen. Vol.9. No.1.

Ponco, Budi. 2008. Analisis Pengaruh CAR, NPL, BOPO, NIM Dan LDR Terhadap ROA Pada Perusahaan Perbankan Yang Terdaftar di Bursa Efek Indonesia Periode 2004-2007. Tesis. Program Studi Magister Manajemen. Program Pascasarjana. Universitas Diponegoro. Semarang.

Triyono dan Yuni Prihadi Utomo. 2004. Studi Komparasi Efektivitas Pengaruh Kebijakan Fiskal dan Moneter dalam Perekonomian Indonesia. Ekobis. Vol.5. No.1a, April : p.79-91.

UU No.10 Tahun 1998 Tentang Perubahan Atas UU Nomor 7 Tahun 1992 Tentang Perbankan.

Weston, J, Fred and Copeland, E, Thomas. 1997. Manajemen Keuangan. Edisi Kesembilan. Binapura Aksara. Jakarta.

World Bank. 1997. World Development Report 1997. New York : Oxford University Press, Inc. 